Original Article

\title{
Detection of enteropathogens and research of pesticide residues in Lactuca sativa from traditional and agroecological fairs
}

\author{
Detecção de enteropatógenos e pesquisa de resíduos de agrotóxicos em Lactuca sativa \\ de feiras tradicionais e agroecológicas
}

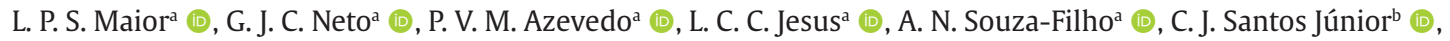

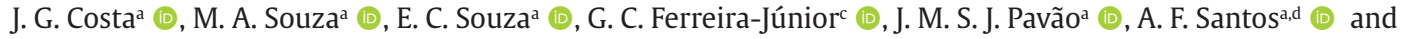 \\ T. J. Matos-Rocha ${ }^{\mathrm{b}, \mathrm{c} *}$ (D) \\ a Centro Universitário Cesmac, Maceió, AL, Brasil \\ ' Universidade Estadual de Ciências da Saúde de Alagoas - UNCISAL, Maceió, AL, Brasil \\ ' Instituto Federal de Educação, Ciência e Tecnologia do Acre - IFAC, Xapuri, AC, Brasil \\ ${ }^{\mathrm{d}}$ Universidade Estadual de Alagoas - UNEAL, Arapiraca, AL, Brasil
}

\begin{abstract}
Agroecological production represents a new reality in vegetable farming. Thus, the study aimed to search for the presence of pesticides in agroecological samples and microbiological and parasitological contamination in Lactuca sativa L. of agroecological and conventional fairs in Alagoas. Thirty-two samples were collected, a hygienicsanitary checklist was performed, along with coliform, Salmonella spp., Staphylococcus aureus research and Gas Chromatography with Mass Spectrometer (GC-MS) for pesticide research; using two methodologies for parasitological studies. Thirty-two samples were analyzed, with a sanitary adequacy level at $45 \%$ and $38 \%$ for fairs (agroecological and conventional) respectively, with three samples (9.4\%) in total, being adequate to the microbiological pattern according to RDC no. 12/2001. Among the 23 samples which were tested positive for parasites, $69.5 \%$ originated from samples extracted at conventional fairs, and $53 \%$ of every positive samples presented Entamoeba coli as the main contaminant. All together, no traces of deltamethrin were detected, but in two of the samples a peak retention for diphenoconazole was detected. In conclusion, the fairs represent an adequate environment for human pathogens and indicators. Therefore greater hygiene training of vegetable traders and consumers in the state of Alagoas is required, especially in conventional fairs, which presented more critical microbiological and parasitological indexes comparing to fairs with agroecological products; however, the presence of difenoconazole in two samples of agricultural fairs suggests accidental contamination or indiscriminate use of this chemical in the production of Lactuca sativa, however, products with agroecological origin represents a better choice for the consumers.
\end{abstract}

Keywords: vegetables, pesticides, microbiological analysis, parasitological analysis.

\section{Resumo}

A produção agroecológica representa uma nova realidade no cultivo das hortaliças. Assim, o estudo teve como objetivo verificar a presença de agrotóxicos em amostras agroecológicas e analisar a contaminação microbiológico e parasitológico em Lactuca sativa L. de feiras agroecológicas e convencionais de Alagoas. Foram coletadas 32 amostras, realizando checklist higiênico-sanitário, análises de coliformes, Salmonella spp., Staphylococcus aureus e Cromatografia Gasosa com Espectrômetro de Massas (GC-MS) para pesquisa de agrotóxicos; utilizando-se duas metodologias para estudos parasitológicos. Foram analisadas 32 amostras, com nível de adequação sanitária de $45 \%$ e $38 \%$ para feiras (agroecológicas e convencionais) respectivamente, sendo três amostras no total $(9,4 \%)$ adequadas a padrão microbiológico segundo RDC n ${ }^{\circ} 12 / / 2001$; Dentre as 23 amostras positivas para parasitos, 69,5\% teve origem em amostras de feiras convencionais, e $53 \%$ de todas as amostras positivas apresentaram Entamoeba coli como principal contaminante, juntamente, não foi detectado traços de deltametrina, porem foi visualizado em duas amostras, pico de retenção para padrão de difenoconazol. Concluindo-se que as feiras representam um ambiente adequado para patógenos humanos e indicadores, necessitando de uma maior higienização e treinamento dos comerciantes e consumidores de hortaliças do estado de Alagoas, principalmente em feiras convencionais, que apresentaram índices microbiológicos e parasitológicos mais críticos em relação a feiras com produtos agroecológicos; mas, a presença de difenoconazole em duas amostras de feiras agroecológicas sugerem contaminação acidental ou uso indiscriminado deste químico em produção da Lactuca sativa L., todavia os produtos de origem agroecológica representam uma melhor escolha para o consumidor.

Palavras-chave: hortaliças, agrotóxicos, análise microbiológica, análise parasitológica.

*e-mail: tmatosrocha@cesmac.edu.br

Received: May 9, 2020 - Accepted: November 13, 2020

This is an Open Access article distributed under the terms of the Creative Commons Attribution License, which permits unrestricted use, distribution, and reproduction in any medium, provided the original work is properly cited. 


\section{Introduction}

Lactuca sativa L., culturally called garden lettuce is the vegetable of the Asteraceae Family with the highest consumption in the world. It is estimated that in 2014 the consumption of this vegetable per Brazilian reached $1.3 \mathrm{~kg}$, stimulating in the following years an investment of $\mathrm{R} \$ 8$ billion, mainly in the traditional and agroecological cultivation of small producers (Brasil, 2014; Queiroz et al., 2017). With the constant search of the world for healthy foods, free of pesticides, arises in Brazil in various crops and products, the growth of food and agroecological fairs, having among the most commercialized vegetables in these environments L. sativa organic (Gazolla et al., 2017). Following the world's growing demand for healthy and pesticide-free food, Brazil presents an arisal of many agroecological food fairs in which the most commercialized product is L. sativa organic (Gazolla et al., 2017).

Food in agroecological fairs often does not have organic certification, and greater monitoring of the presence or nonpresence of pesticides in their products should be carried out (Peres et al., 2016; Silva et al., 2016). Although the products sold at agroecological fairs presents advantages to human and environmental health, incorrect handling at the point of commercialization and storage at the fairs may transform the product into a pathogen transmitter and food health indicators, revealing the debility fair (Novacki et al., 2016).

Therefore, it is necessary according to Brasil (2001) and ICMSF (2011) the correct analysis of the microbiological profile, through the research of bacteria of the Enterobacteriaceae family, such as total and thermotolerant coliforms, since they are considered hygienic sanitary indicators, as well as the presence of Escherichia coli and Salmonella spp., due to the fact that they are major causes of pathologies, such as intestinal infections, which in some cases lead to diarrhea and acute dehydration.

Together, the research and quantification of coagulasepositive Staphylococcus should be performed in all food products, mainly in vegetables, because it's presence is related to the magnitude level of product management and the microorganism's ability to cause acute intestinal infection through its thermotolerant toxin (CDC, 2018). For a complete health profile, it is necessary, along with the microbiological data, the parasitologic study of the sample, since Karshima (2018) and Domenech et al. (2018), have already found parasites of clinical importance such as Ascaris lumbricoides, Entamoeba histolytica/Entamoeba dispar, Enterobius vermicularis, Hymenolepis nana, Toxocara spp., Giardia lamblia in vegetables of the L. sativa family, as well as the study of hygienic-sanitary conformities and non-conformities of the vegetable marketing environment.

Thus, the work focused on evaluating the presence of deltamethrin and difenoconazole in the vegetables of the agricultural and ecological fairs and evaluating the L. sativa commercialized in agricultural and conventional fairs, through indicators and microbial pathogens and parasites of clinical and sanitary importance, as well as to evaluate the integrity of the vegetable marketing environment in the hygienic-sanitary and environmental vision.

\section{Material and Methods}

A cross-sectional and comparative analytical observational study was carried out, with morning collections of L. sativa, with a minimum weight of $50 \mathrm{~g}$. Sixteen fairs previously registered and located in the metropolitan areas of Agreste, Zona da Mata and Maceió from February to September 2018 were selected, 50\% of these were agroecological trade fairs and the other $50 \%$ were traditional products trade fairs, two collections were held at each fair in different periods (Alagoas, 2018; Gílio, 2012).

We considered sample units L. sativa from organic cultivation in agroecological fairs, and conventional cultivation for traditional fairs, where all samples were sent for laboratory analysis in conjunction with the in loco collection the application of an observational checklist of the trading environment, according to RDC no. 275 (Brasil, 2001).

For bacteriological analysis, the American Public Health Association '9:2015 multiple tube methodology 9:2015 (APHA) was used for total coliform and thermotolerant (Kornacki et al., 2015), counting combined with the Methodology of the International Organization for Standardization (ISO) number 6579 (ISO, 2017) and 39:2015 of the APHA (Bennett et al., 2015) for the research of Salmonella spp. and Staphylococcus aureus, respectively. For statistical treatment, the Wilcoxon test was used, comparing the microbiological results from the samples of the agricultural and conventional fairs. Lutz and Baermann-Moraes techniques were used to identify the parasites, and in every techniques, three readings of the sample were performed through optical microscope in objective lenses with $10 \mathrm{x}$ and $40 \mathrm{x}$ magnification.

In the detection of pesticides, deltamethrin standard solutions were first performed at concentrations of 0.1 ppm, 0.5 ppm, 1 ppm, 3 ppm and 6 ppm (Figure 1), and concentrations with difenoconazole at $0.05 \mathrm{ppm}, 0.1 \mathrm{ppm}$, $0.5 \mathrm{ppm}, 1 \mathrm{ppm}, 3 \mathrm{ppm}$ and $10 \mathrm{ppm}$ (Figure 2), aiming to develop both calibration and concentration curves of the studied compounds.

During the analytical phase for the presence of pesticides, the first eight samples collected at the agricultural fairs were selected, the extraction of the compounds of these vegetables was prepared in soxhlet system with Ethyl Acetate (99.5\% v/v) as extraction solution, later chromatography analyses were performed with repetition in a Gas Chromatograph coupled to a Mass Spectrometer (GC-MS) model GCMS-QP2010 from the

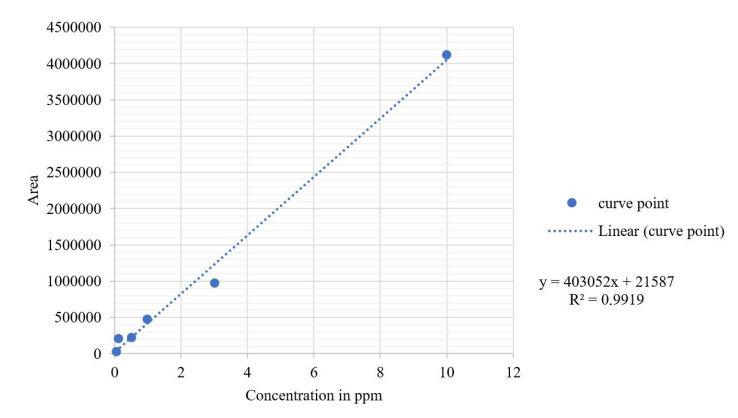

Figure 1. Deltamethrin calibration curve. 


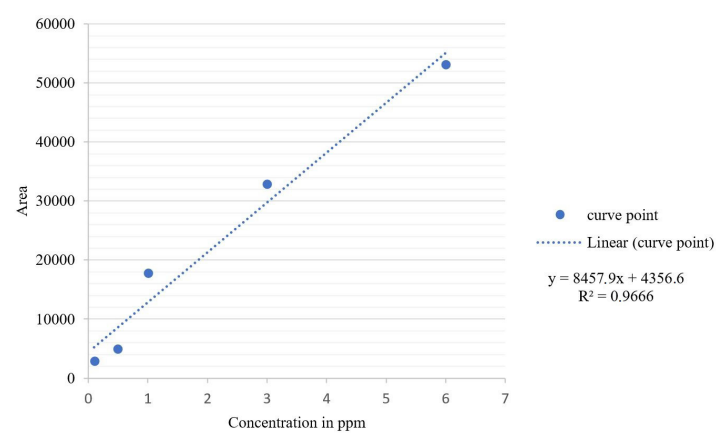

Figure 2. Difenoconazole calibration curve.

company Shimadzu, equipped with DB1 capillary column $(30 \mathrm{~m} \times 0.25 \mathrm{~mm} \times 250 \mu \mathrm{m})$, and helium gas running schedule at $0.84 \mathrm{~mL} / \mathrm{min}$ as carrier gas, split injector at $220^{\circ} \mathrm{C}$ and FID detector (flame ionization detector) at $280^{\circ} \mathrm{C}$; the oven temperature was 220 to $300^{\circ} \mathrm{C}$ with a heating ramp of $15^{\circ} \mathrm{C} /$ min and running time of 44 minutes. Both the retention time and peaks area obtained during chromatography were observed, thus comparing the results obtained with the patterns of pesticides studied.

\section{Results and Discussion}

\subsection{Analysis of public organic fairs}

The visits happened at each of the 16 collect spots, where 32 samples were collected. 22 (86.8\%) of these were obtained in Maceio's Metropolitan Region (MMR), $6(18.75 \%)$ in the Agreste's Metropolitan Region (AMR) and $4(12,5 \%)$ in the Zona da Mata's Metropolitan Region (ZMMR). Today,these metropolitan regions are responsible for supplying the market for more than 2 million habitant, thus representing $63 \%$ of the population of Alagoas (Santos Filho et al., 2017)

At both kinds of fairs (agroecological and conventional) it was observed a sanitary adequacy level of $45 \%$ and $38 \%$, respectively. Revealing a much larger concern by the merchants from the agroecological fairs to keep the hygiene of the environment as well as the food served to the population but the results are still below the ones accepted by ANVISA's RDC n ${ }^{\circ} 275 / 2002$.

A correlactive scenery was observed by Gilio (2012), where $53 \%$ of Alagoa's conventional fairs were classified as terrible/bad for hygiene, as well as Silva et al. (2016) which revealed the precariousness of fairs and products in a city of Alagoas. By comparing with metropolitan areas, the fairs located in MMR and ZMMR regions presented contrasting results that goes from low to high risking fairs, while the fairs in the AMR region present discreet variation and best sanitary results. Therefore, it is observed that, on average, the fairs products studied presents a high risk to population's health and that in most cases is related to educational and cultural factors (Minnaert and Freitas, 2010). Only five fairs (15.7\%) presented a hygienic and environmental care of the food as expected for the commercialization of L. sativa.

\subsection{Microbiological and parasitological analysis}

Over microbiological analysis, it was observed that from the 32 samples analysed, five (15.7\%) presented levels of thermotolerant coliforms lower than $100 \mathrm{NMP} / \mathrm{g}$, thus classifying these samples as accepted to food and environmental safety according to RDC no. 12 (Brasil, 2001), however, 27 of the samples (84.3\%) presented values over $100 \mathrm{NMP} / \mathrm{g}$, with an average of $790 \mathrm{NMP} / \mathrm{g}$ thus classifying a high sample contamination, where it was observed a variation of $1.73 \%$ between average results from organic and conventional fairs. Yet during Salmonella spp. research analysis, from the 32 studied samples, in 22 (68\%) of them the microorganism was absent, while 10 samples (23\%) presented it, thus characterizing the samples as unsuitable for consuming. According to the RDC no. 12 (Brasil, 2001), L. sativa must not contain Salmonella spp, there was no significant difference between the number of samples with or without the microorganism at the two types of fairs.

During $S$. aureus detecting research, 18 samples (56\%) with were found suitable according to RDC no. 12 (Brasil, 2001), and 10 of these samples were acquired from agroecological fairs and seven from conventional fairs. According to legislation, only when completely adequate concerning microorganisms the product can be considered adequate, therefore, only three samples (9.4\%) presented acceptable patterns for every microorganisms, being a sample from the first visit and the two others from the second visits, but in a statistical level there was no difference concerning the quantitative of coliform group bacteria, thus being observed an average of 793.00 $\pm 475.52 \mathrm{NMP} / \mathrm{g}$ and $792.56 \pm 476.27 \mathrm{NMP} / \mathrm{g}$ for total and thermotolerant coliforms in agroecological samples, and $968.87 \pm 369.28 \mathrm{NMP} / \mathrm{g}$ and $926.44 \pm 377.13 \mathrm{NMP} / \mathrm{g}$ for total and thermotolerant coliforms in conventional samples. Salmonella spp. presence was equally found in agroecological and conventional samples, with $31.25 \%$ of them positive for Salmonella spp. (Table 1). The samples showed a statistical difference of over $5 \%$ probability that the ammount of $S$. aureus is lower in agroecological fairs comparing to conventional fairs, with a mean variation of $2387.94 \pm 4912.03 \mathrm{UFC} / \mathrm{g}$ and $3207.56 \pm 5475.45$ UFC/g of $S$. aureus in agroecological and conventional samples respectively. In sanitary hygiene fair adequacy the agroecological fairs presented statistically better mean $(56.69 \pm 29.43)$ by comparing with conventional (34.47 $\pm 28.61 \%)$.

By analyzing free fairs in the city of Uberlândia, França et al. (2009) found similar data, confirming the trend of high load of total coliforms, as in correlation samples with $1.1 \times 10^{3} \mathrm{NMP} / \mathrm{g}$ of thermotolerant coliforms. In contrast, Abreu et al. (2010) by analyzing L. sativa recently harvested in the field, found total and thermotolerant coliforms present in only $14 \%$ of their samples, thus suggesting that most of the contamination occurs during transport and commercialization of the product. Futhermore the high rate of thermotolerant coliforms suggests a more aggravated reality of the samples, since it indicates poor hygienic-sanitary conditions granted by the state towards their fairs, therefore the presence of these microorganisms demonstrates the direct contact of vegetables with 
Table 1. Average data and standard deviation of microbiological contamination in L. sativa from organic and conventional cultivation.

\begin{tabular}{ccc}
\hline Variable $\mid$ Product & Organic & Conventional \\
\hline Total coliform & $793.00 \pm 475.52 \mathrm{a}$ & $964.87 \pm 369.28 \mathrm{a}$ \\
Thermotolerant coliform & $792.56 \pm 476.27 \mathrm{a}$ & $926.44 \pm 377.13 \mathrm{a}$ \\
Staphylococcus aureus & $2387.94 \pm 4912.03 \mathrm{a}$ & $3207.56 \pm 5475.45 \mathrm{~b}$ \\
Salmonella spp (\% present) & $31.25 \mathrm{a}$ & $31.25 \mathrm{a}$ \\
Adequacy (\%) & $56.69 \pm 29.43 \mathrm{a}$ & $34.47 \pm 28.61 \mathrm{~b}$ \\
\hline
\end{tabular}

Averages followed by the same letter do not differ statistically to the $5 \%$ Wilcoxon probability test.

environments contaminated with human or animal feces (Silva et al., 2016).

Regarding the presence and absence of Salmonella spp., Arbos et al. (2010) found a correlative scenario in their analyses, by evaluating samples from agroecological and conventional producers, found two of the 60 samples with Salmonella spp. present in $25 \mathrm{~g}$, suggesting a low rate of contamination of this microorganism in vegetables, however, the minimal presence is worrisome, since this food pathogen tends to develop several pathologies in humans.

All metropolitan regions had positive samples for Salmonella spp., revealing its wide geographic distribution. The presence of $S$. aureus in the studied samples suggests danger to the population, since Yu et al. (2018) classifies it as one of the main pathogens causing food pathologies, with emphasis on intoxications. This microorganism proves to be an excellent indicator of manipulation of objects and food, because it is part of the microbiota of the skin and mucosa of the human being (Brooks et al., 2014). Therefore, the samples found with high value of $S$. aureus may indicate a greater presence of pathogens and hygienic-sanitary indicators obtained in the transport and commercialization of the product.

Only three samples (9.4\%) presented their bacteriological values within the acceptable standard, being $100 \%$ of agroecological origin, however, the collection environment may not have been decisive for the bacteriological load, since Lima (2008) by observing the endophytic microbiota and the structural alterations of $L$. sativa in different crops, recognized a growth resistance to contaminants in agroecological samples, thus suggesting that the appropriate samples for consumption may present a natural resistance to the development of contaminants and pathogens.

However, because many of these microorganisms are also found in a natural or infectious way in humans (Mello et al., 2018), contamination may or may not originate from vegetables may or may not come directly from the marketer of the fairs, since it was observed by the study of the presence of S. aureus in the samples, $43 \%$ with a high degree of contamination, as a consequence of manipulation. Thus revealing the need for further studies and a selective screening of the resistance of environmental microorganisms, in order to try to understand the roles of human action.

In parasitological analysis, in the studied samples 10 species of enteric parasites were detected in 23 samples (71.8\%), being $69.5 \%$ acquired in conventional fairs and
Table 2. Results of the presence of deltamethrin and diphenoconazole in the studied samples regarding their Market origin.

\begin{tabular}{ccc}
\hline Collected fairs & Deltametrhrin & Diphenoconazole \\
\hline ARA 01 & ND & ND \\
ARA 02 & ND & $0.03 \mathrm{ppm}$ \\
MAC 01 & ND & ND \\
MAC 02 & ND & $0.17 \mathrm{ppm}$ \\
MAC 03 & ND & ND \\
MAC04 & ND & ND \\
MAC05 & ND & ND \\
ZMA01 & ND & ND \\
\hline
\end{tabular}

ND: non detected.

$30.5 \%$ in agroecological fairs. Among the positive for enteric parasites samples, 53\% presented Entamoeba coli as main contaminant and in lower expression. Commensal parasites like Iodamoeba butschlii, Endolimax nana and Entamoeba hartmanni. In $34 \%$ of the samples the E. histolyrica/ E. dispar was present and $25 \%$ there was eggs from $A$. lumbricoides, being the most present helminth during the study. It was observed a higher prevalence of negative for enteroparasites samples in organic cultivation samples, revealing it as a better manner of cultivation, transport and commercialization of the products, as Rocha et al. (2008) describe that the contamination of the urban and rural enviroment is generally seen in developing countries, being the vegetables the main sort of transmission, hence suggesting that organic cultures may be a safer option due to water and irrigation control of the fairs.

\subsection{Detection of pesticide residues}

No trace of deltamethrin was detected in the studied samples (Table 2), being identified in the samples from ARA01 and MAC02 fairs, peak retention in time and area compatible with diphenoconazole's pattern (Figure 3), being confirmed its similarity, realizing integration of the peak and detected area with cromatograph's library, with $95 \%$ of similarity.

Although Brasil (2019) recommends the Maximum Residue Limits (MRL) for lettuce to be a sample of $0.5 \mathrm{mg}$ / $\mathrm{kg}$, any presence of agrochemicals suggests the loss of the characteristic of being a organic product, since according to Normative Instruction No. 17 of June 18, 2014: “The use 

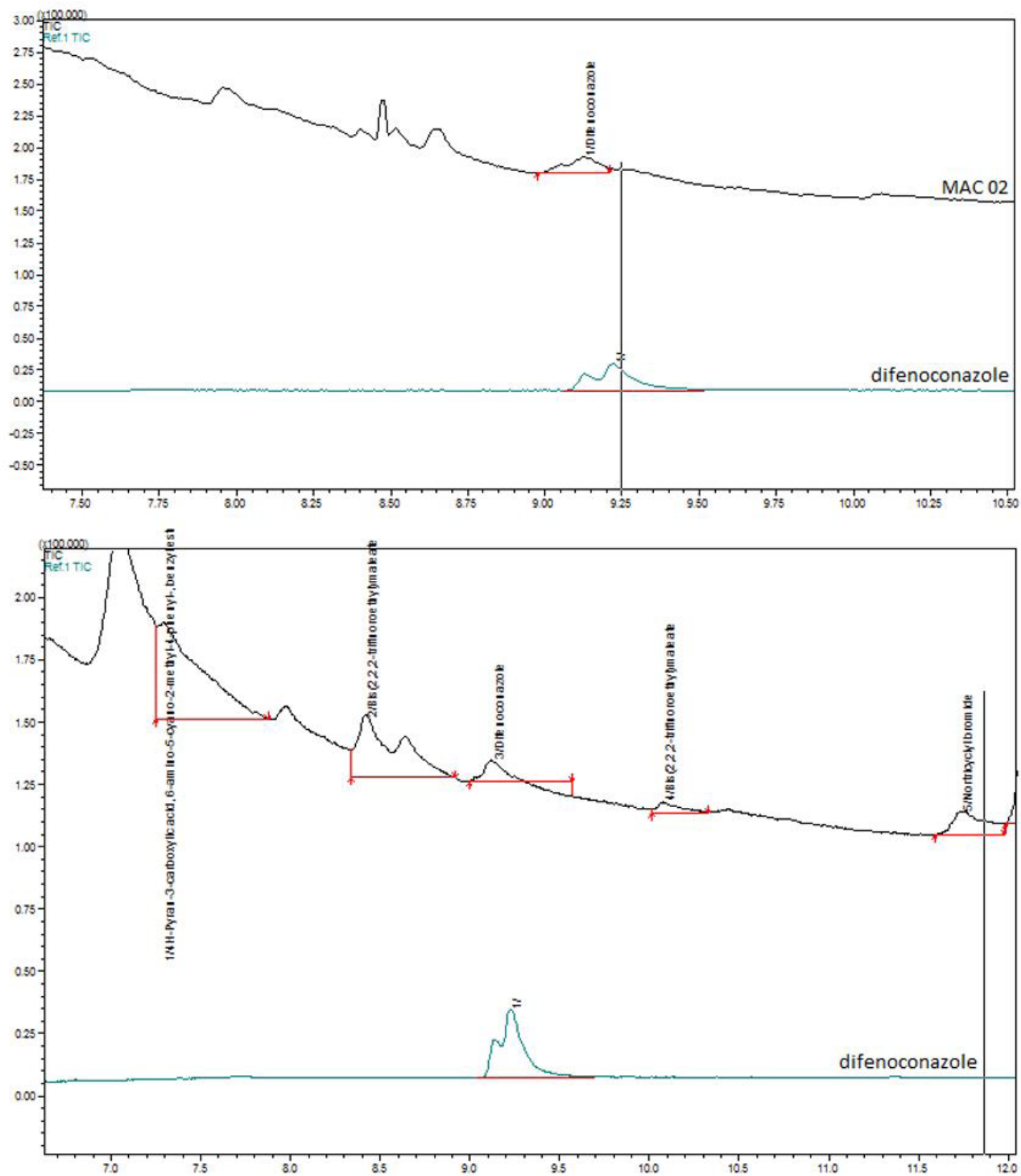

Figure 3. Chromatogram from the sample fairs MAC 02 and ARA 0, with the peaks of Diphenoconazole compared with the pattern.

of synthetic pesticides in the treatment and storage of seeds and seedlings is prohibited". Classifying products from fairs ARA01 and MAC02, as products unsuitable for the environment, mainly due to the fact that law no. 10,831 of December 23, 2003, states that the organic products are characterized by the "sustainable and not harmful to the local ecosystem extraction " production . Freitas (2015) presented that producers of the Metropolitan Region of Agreste de Alagoas (MRAA) widely use fungicide compounds with difenoconazole as an active ingredient, while Silva et al. (2014), describes that $30.36 \%$ of the producers studied in AMR, use pesticides containing deltamethrin in the L. sativa crop.

Making these compounds an accidental or usual source of contamination of olericultures, since compounds such as difenoconazole, presents intermediate risk to contamination of groundwater and a long half-life in the atmosphere (Milhome et al., 2009). Suggesting an accidental contamination of the vegetable by irrigation water or by transporting the sample together with contaminated samples, mainly due to the fact that the agricultural fairs studied, are formed by family producers, who according 
to law no. $10,831 / 2003$, do not require certification of the production and transport of the product, thus leading to a greater doubt regarding the methods of transport and production of vegetables.

However, Queiroz et al. (2012) when studying 29 agrochemicals in samples of L. sativa, witnessed a similar result for the absence of deltamethrin, as well as Reis et al. (2020) in studies with organic and conventional vegetables, confirming the commitment of producers not to use this pesticide, which according to Brasil (2016) should not be used in the cultivation of L. sativa. In conjunction with the environmental aspects, the absence of these compounds brings health to the producer and the final consumer, since difenoconazole can affect the functional structure of human erythrocytes, as well as deltamethrin by causing cellular apoptosis (Chi et al., 2014). However, the presence or absence of deltamethrin or/and diphenoconazole do not fully confirm the organic characteristic of the product, but, according to the chromatograms obtained, there was no study of the areas and peaks, indications of other agrochemicals, which may suggest products of organic origin.

The results allow to conclude the microbiological and parasitological contamination of the vegetables in natura analyzed, thus evidencing the value of microbiological and parasitic monitoring of $L$. sativa sold in organic and conventional fairs, avoiding possible human health complications. The presence of diphenoconazole suggests the accidental contamination or the usage of this pesticide during organic lettuce production, thus leading the need for higher rigor in legislation and supervisory organs towards verifying the authenticity of the agroechological foods sold in the state. Correct higienization practices of L. sativa are needed by the population and the production of educational booklets and training with conventional and agroechological merchants, with incentives towards production, commercialization, consumption fiscalization of agroechological products.

\section{References}

ABREU, I.M.O., JUNQUEIRA, A.M.R., PEIXOTO, J.R. and OLIVEIRA, S.A., 2010. Qualidade microbiológica e produtividade de alface sob adubação química e orgânica. Food Science and Technology, vol. 30, pp. 108-118. http://dx.doi.org/10.1590/ S0101-20612010000500018.

ALAGOAS. Superintendência de Inclusão Produtiva - SUPIP, 2018. Relação de lideranças e agricultores/as que apoiam feiras orgânicas e feiras agroecológicas em Maceió-AL. Maceió: SUPIP, 3 p.

ARBOS, K.A., FREITAS, R.J.S., STERTZ, S.C. and CARVALHO, L.A., 2010. Segurança alimentar de hortaliças orgânicas: aspectos sanitários e nutricionais. Ciência e Tecnologia de Alimentos, vol. 30, pp. 215-220. http://dx.doi.org/10.1590/S0101-20612010000500033.

BENNETT, R.W., HAIT, J.M. and TALLENT, S.M., 2015. Staphylococcus aureus and Staphylococcal enterotoxins. In: Y. SALFINGER and M.L. TORTORELLO. Compendium of methods for the microbiological examination of foods. 5th ed. Washington: American Public Health Association. Cap. 39.

BRASIL, 2001 [viewed 19 March 2019]. Resolução da Diretoria Colegiada $n^{0} 12$, de 2 de fevereiro de 2001. Regulamento técnico sobre padrões microbiológicos para alimentos [online]. Diário Oficial da República Federativa do Brasil, Brasília. Available from: http://bvsms.saude.gov.br/bvs/saudelegis/anvisa/2001/ res0012_02_01_2001.html

BRASIL. Agência Nacional de Vigilância Sanitária, 2019. Programa de Análise de Resíduos de Agrotóxicos em Alimentos - PARA. Brasilia: Agência Nacional de Vigilância Sanitária, pp. 27-29.

BRASIL. Centro de Gestão e Estudos Estratégicos, 2014. Consumo de alimentos: implicações para a produção agropecuária. Sustentabilidade e sustentação da produção de alimentos no Brasil. Brasília, $172 \mathrm{p}$.

BRASIL. Programa de Análise de Resíduos de Agrotóxicos em Alimentos - PARA. Gerência-geral de Toxicologia, 2016. Relatório das análises de amostras monitoradas no período de 2013 a 2015. Brasília: Agência Nacional de Vigilância Sanitária. 246 p.

BROOKS, G.F., CARROLL, K.C., BUTEL, J.S., MORSE, S.A. and MIETZNER, T.A., 2014. Microbiologia médica. 26. ed. Porto Alegre: AMGH, 840 p.

CENTERS FOR DISEASE CONTROL AND PREVENTION - CDC, 2018 [viewed 10 May 2019]. Drinking water [online]. Available from: https://www.cdc.gov/healthywater/drinking/private/ wells/testing.html

CHI, C.C., CHOU, C.T., LIANG, W.Z. and JAN, C.R., 2014. Effect of the pesticide, deltamethrin, on $\mathrm{Ca}^{2+}$ signaling and apoptosis in OC2 human oral cancer cells. Drug and Chemical Toxicology, vol. 37, no. 1, pp. 25-31. http://dx.doi.org/10.3109/01480545.2 013.806528. PMid:23829777.

DOMENECH, E., AMORÓS, I., MORENO, Y. and ALONSO, J.L., 2018. Cryptosporidium and Giardia safety margin increase in leafy green vegetables irrigated with treated wastewater. International Journal of Hygiene and Environmental Health, vol. 221, no. 1, pp. 112-119. http://dx.doi.org/10.1016/j.ijheh.2017.10.009. PMid:29066286.

FRANÇA, B.R., BONNAS, D.S. and SILVA, C.M. O., 2009. Qualidade higiênico sanitária de alfaces (Lactuca sativa) comercializadas em feiras livres na cidade de Uberlândia, MG, Brasil. Bioscience Journal, vol. 30, no. 1, pp. 458-466.

FREITAS, S.P., 2015. Avaliação da sensibilidade de isolados de Cercospora lactucae-sativae Sawada a estrobilurinas e avaliação de componentes epidemiológicos entre isolados sensíveis $e$ resistentes. Rio Largo: Universidade Federal de Alagoas, 55 p. Tese de Doutorado em Proteção de Plantas.

GAZOLLA, M., AQUINO, J.R. and SIMONETTI, A.L., 2017. Análise das condições socioeconômicas e vulnerabilidades produtivas dos agricultores familiares pobres do Paraná. Revista Paranaense de Desenvolvimento, vol. 38, no. 133, pp. 1-133.

GÍLIO, I., 2012. Feiras livres de Alagoas. Maceió: Desenvolve, pp.113.

INTERNATIONAL COMMISSION ON MICROBIOLOGICAL SPECIFICATIONS FOR FOODS - ICMSF, 2011. Use of data for assessing process control and product acceptance. 8th ed. Boston: Springer. Microorganisms in Foods, no. 8. https://doi. org/10.1007/978-1-4419-9374-8.

INTERNATIONAL ORGANIZATION FOR STANDARDIZATION - ISO, 2017 [viewed 10 July 2017]. ISO 6579: Horizontal method for the detection, enumeration and serotyping of Salmonella. 1st ed. Paris: ISO. 50 p. Available from: https://www.iso.org/ standard/56712.html

KARSHIMA, S.N., 2018. Parasites of importance for human health on edible fruits and vegetables in Nigeria: a systematic review and meta-analysis of published data. Pathogens and Global Health, vol. 112, no. 1, pp. 47-55. http://dx.doi.org/10.1080/20 477724.2018.1425604. PMid:29336229.

KORNACKI, J.L., GURTLER, J.B. and STAWICK, B.A. Enterobacteriaceae, Coliforms, and Escherichia coli as quality and safety indicators. In: Y. SALFINGER and M.L. TORTORELLO. Compendium of methods 
for the microbiological examination of foods. 5. ed. Washington: American Public Health Association, 2015. Cap. 9, pp. 103-120.

LIMA, P.M., 2008. Influência da microbiota natural e de fatores fisicoquímicos na adesão de Salmonella enteritidis em alface de cultivo hidropônico e convencional. Viçosa: Universidade Federal de Viçosa, 71 p. Dissertação de Mestrado em Ciência e Tecnologia de Alimentos.

MELLO, C.S., RODRIGUES, M.S.C., ARAÚJO FILHO, H.B., MELLI, L.C.F.L. TAHAN, S., PIGNATARI, A.C.C. and DE MORAIS, M.B., 2018. Fecal microbiota analysis of children with small intestinal bacterial overgrowth among residents of an urban slum in Brazil. Jornal de Pediatria, vol. 94, no. 5, pp. 483-490. http://dx.doi.org/10.1016/j. jped.2017.09.003. PMid:29049893.

MILHOME, M.A.L., SOUSA, D.O.B., LIMA, F.A.F. and NASCIMENTO, R.F., 2009. Avaliação do potencial de contaminação de águas superficiais e subterrâneas por pesticidas aplicados na agricultura do Baixo Jaguaribe, CE. Engenharia Sanitaria e Ambiental, vol. 14, no. 3, pp. 363-372. http://dx.doi.org/10.1590/ S1413-41522009000300010.

MINNAERT, A.C. and FREITAS, M.C., 2010. Práticas de higiene em uma feira livre da cidade de Salvador (BA). Ciencia E Saude Coletiva, vol. 15, no. 1, suppl. 1, pp. 1607-1614. http://dx.doi. org/10.1590/S1413-81232010000700072. PMid:20640322.

NOVACKI, J.F., BARCELOS, I.B., VALIATTI, T.B. and GÓIS, R.V., 2016. Análise parasitológica de alfaces (Lactuca sativa) comercializadas em um feirão do município de Ji-paraná, Rondônia. Revista Uningá Review, vol. 29, no. 1, pp. 1-14.

PERES, J.G., BOSCHI, R.S., SOUZA, C.F. and MENDONÇA, T.G., 2016. Produtividade da água para seleção de cultivares de alface José. Revista Ciência, Tecnologia \& Ambiente, vol. 3, no. 1, pp. 1-7.

QUEIROZ, A., CRUVINEL, V. and FIGUEIREDO, K., 2017. Produção de alface americana em função da fertilização com organomineral. Enciclopédia Biosfera, vol. 14, no. 25, pp. 1053-1063. http:// dx.doi.org/10.18677/encibio_2017a84.
QUEIROZ, S.C., FERRACINI, V.L. and ROSA, M.A., 2012. Validação de método multirresíduo para determinação de pesticidas em alimentos empregando QuEChERs e UPLC-MS/MS. Química Nova, vol. 35, no., 1, pp. 185-192. http://dx.doi.org/10.1590/ S0100-40422012000100032.

REIS, R.S., CASTRO, M.F. and DEXHEIMER, G.M., 2020. Análise parasitológica de hortaliças e avaliação dos cuidados e conhecimentos para o consumo in natura pela população. Revista Brasileira Multidisciplinar, vol. 23, no. 2, pp. 136144. http://dx.doi.org/10.25061/2527-2675/ReBraM/2020. v23i2.767.

ROCHA, A., MENDES, R. and BARBOSA, C.S., 2008. Strongyloides spp e outros parasitos encontrados em alfaces (Lactuca sativa). Revista de Patologia Tropical, vol. 37, no. 2, pp. 1-10. http:// dx.doi.org/10.5216/rpt.v37i2.5046.

SANTOS FILHO, C., SILVA, P.R.F. and MELO, J.C. 2017 As regiões metropolitanas de alagoas: significados e realidades diversas. In: Anais do III Seminário regional comércio, consumo e cultura nas cidades, 2017, Sobral. Sobral: SRCCC, pp. 1-20.

SILVA, A.S., SILVA, S.S., ALBUQUERQUE-NETO, J.C., SOUZA, A.A. and SANTOS, A.L., 2014. Levantamento da utilização de agrotóxicos nas culturas de alface, cebolinha e coentro no município de Arapiraca-AL. Horticultura Brasileira, vol. 31, pp. S0316-S0323.

SILVA, D.D.E., FELIZMINO, F.T.A. and OLIVEIRA, M.G., 2016. Avaliação da degradação ambiental a partir da prática da cultura do feijão no município de Tavares-PB. Holos, vol. 8, pp. 148-166. http:// dx.doi.org/10.15628/holos.2015.2063.

YU, Y.C., YUM, S.J., JEON, D.Y. and JEONG, H.G., 2018. Analysis of the microbiota on lettuce (Lactuca sativa L.) cultivated in South Korea to identify foodborne pathogens. Journal of Microbiology and Biotechnology, vol. 28, no. 8, pp. 1318-1331. http://dx.doi. org/10.4014/jmb.1803.03007. PMid:30301312. 